\title{
原子の世界を体験する
}

\author{
金 山 敏 彦 \\ アトムテクノロジー研究体, 産業技郝融合領域研究所 305-8562 茨城県つくば市東 1-1-4 \\ (1999 年 6 月 21 日受理)
}

\section{Experimental Introduction into the Atomic World}

Toshihiko KANAYAMA

\begin{abstract}
Joint Research Center for Atom Technology, National Institute for Advanced Interdisciplinary Research
\end{abstract} 1-1-4 Higashi, Tsukuba, Ibaraki 305-8562

(Received June 21, 1999)

\begin{abstract}
This article describes a series of demonstration experiments, which were exhibited to general visitors in open days of our research institute. The intention is to provide the people with an opportunity to actually experience by themselves why and how atoms assemble to form various types of materials. At the same time, these experiments are designed to be an enjoyable introduction to our research activity.
\end{abstract}

\section{1.はじめに}

管者の所属する工業技術院の研究所では，ほぼ毎年 1 回, 所内の一般公開を行っている。ここで紹介するのは, 96 年から昨夏までの一般公開時に行ったアトラクショ ン実験の一部である。これらの出し物は, 見ておるしろ いといらより，自分であれこれさわって楽しめると同時 に，筆者のグループの研究内容の紹介となることを意図 している。

理科離れが叫ばれるようになって久しい。ことは若者 だけではなく，一般の非専門家にとっても，最先端の科 学や技術は急速に，内容が窥いしれないブラックボック スとなっていることが愳念される。心配の対象は，科学 そのむのだけではない。それを研究している研究所む, ますます瑓遠な存在に受け取られているのではないだろ らか。これが, 公開を続けている理由である。ところで, 筆者の研究室には, クリーンルームの中に超高真空装置 や走查型トンネル顕微鏡が並んでいる。この研究現場を 単にかいま見ただけでは, 研究所に親しむどころか, 逆 の印象を持ちかねない。

以下に紹介する実験では, 完成品の装置や器具だけを

E-mail: kanayama@jrcat.or.jp
使うむのは 1つむない。あり合わせの材料で䈉者が手作 りしたものが, ほとんどである。これには，我々がびか びかの高級車を乗り回すように完成した装置を操って研 究しているのではなく, 研究者の発案と工夫で道具を作 り，ミクロな世界に迫っているといらことを，少しでも 感じ取ってもらいたいという意図が込められている。

といらわけで, 以下に述へるのは, 科学マジックショ 一ではなく, 研究内容紹介の序章である。一連のコース を用意してはいるものの, フルコースといらよりはオー ドブルだ。それぞれの実験はすべて参加者に手を下して もらうが, 研究者が立ち会って意味合いを説明している。 むしろ,メインディッシュは, 本稿では触れないその説 明にある。

とは言っても，どんな研究内容を紹介したいかを少し だけ龍しておこう。篗者は現在, アトムテクノロジーな るプロジェクトに従事している。その名の通り,このプ ロジェクトでは, 物筫の成り立ちを原子の単位で制御す ることを目的に, 固体表面や超高真空の空閒中で原子や 分子の反応や㠜集の挙動を皤察し操作する技術を研究し ている。これに対応して，ここで取り上げている一連の 実験のテーマは，一言でいえば，原子がなぜ如何に凝集 して棣々な物質を形成するかである。日常的な道具立て でも，ほんのちょっと工夫すれば未知の状況が現れて意 
外に楽しめることを体験し, 研究が普段の生活とそれ程 かけ離れた世界ではないことを理解してもらうことを期 待している。

\section{2. 原子の世界を体験する実験コース}

\section{1 原子の間に動く力を実感しよう一鉛の圧着}

コースのはじめには, 通りすがりの人々の関心を引き つける, インパクトのある実験が必要である。そこでガ リレオ工房のアイディア1を措りした。はじめに，鉛 でできている魚釣りの重り(ナス 10 号など，釣具店で $¥ 80$ 程度)にひもをつけたものを用意しておく(Fig. 1)。 $2 つ$ 重りの端をカッターナイフでできるだけ平らに削 ってフレッシュな面を出し，押しつける（少しねじりを 加えるのがこつ）と，ひとりでにくっついてしまう。ふ つうの鉛の表面は酸化して黒ずんでいるので, カッター ナイフで削りだした酸化していない金属光沢面との違い は一目でわかる。これをもう一度, 引きはがすのに何 $\mathrm{kg}$ の力を要するかを, Fig.1のよ5な仕組みで, 各自に 計ってもらう。市販のバネばかり (Do-it-yourself店で ¥1,500 位) にテフロン製のリング（Fig.1 でバネばか りに巻いた白い鉢卷き）を取り付け，最高値が読めるよ うに工夫した。

くっつけた重りが耐えられる力は, かなり雑に䏴って も $1 \mathrm{~kg}$ 近く, 慎重に削って接触面樻を增すと $5 \mathrm{~kg}$ 位に はなる。これまでの最高は, 用意したバネばかりの測定 限界 $10 \mathrm{~kg}$ 以上を記録した。この実験はなかなか人気が あり, $5 \mathrm{~kg}$ 以上を出した人の名前を壁に貼りだしたこと もあって, 1 時間以上粘って記録をねらう人も現れた。 このように重りを引きはがすには意外に強い力を要する ので, はがれた瞬間に力余ってつんのめったり, バネば かりのバネの力で重りが飛んでしまらなど, 安全に注意 する必要がある。カッターナイフでけがをするような人 は一人もいなかったが, 皆, 重りを削るのに熱中してし まらので, カバーがないと机が傷だらけになる。このた めに我々は大判のプラスチック下敷きを使って, 重宝し ている。

このデモ実験のねらいは, 固体の凝縮力を体感しても らうことた。破断力を計測した後に破断面を見ると，実 際にくっついていた面積はごくわずかなのに気づく。鉛 のような金属の原子の間には互いに強い力が墈いてい て, 固体としての鉛を形作っている。ふたたん鉛の重りを 手にした時にこれに気つかかいのは, 表面が酸化物や水 分などでおおおれてしまっているためである。これを取 り除いて，適当な条件の下で鉛の原子どうしを近うける と,ひとりでに合体してしまう。これは, 合体した方が, エネルキー的に安定な状態になることに基うくく。

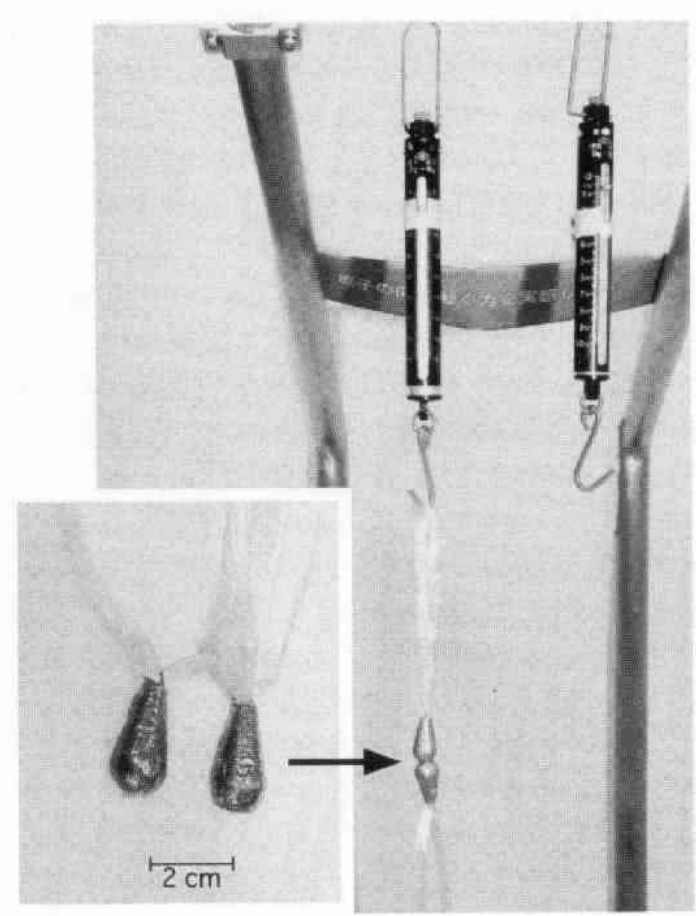

Fig. 1 Bonding experiment of lead fishing weights.

この状況は, 我々が行っている研究内容を象徴してい る。実際の研究では, 鉛の重りではなく, 原子や分子を 超高真空中のイオントラップ2) や固体の清浄表面上で操 作し, 結合させることでナノ構造を作製している。つま りは, 不要な夾雑物を取り除き, 目的の原子本来の結合 を生じさせることで, 自己形成的に構造を作る点が共通 している。鉛の重りを接触させただけで, 予想外に強固 に接合するという意外性の他に, この共通性がコース最 初のイントロダクションに格好である。この実験で酸化 膜をはぎ取る効果を実感してもらうと, 実際の研究では なぜ超高真空が必要かが無理なく説明できる。

ということは, 鉿だけではなく同じような接合が, す べての固体材料について行えるはずである。実際, 超高 真空下で原子的に平坦な表面に対してはそうであること は, 本紙の読者は先刻こ承知であろう。鉛がこのデモン ストレーションに適しているのは, 酸化の進行速度が遅 いことと, 柔らかいので組成変形を起こすことで接触面 積が著しく大きくなることである。

\section{2 原子を引きはがそう一脆性破壊と疲労破壊}

も5少し固い材料で, 原子間の結合を体験するのが次 のテーマで, シリコンとアルミ合金の薄片を壊して橾い を体感してみる。我々のグループは, 主に Si を研究対 象としている。また, 新聞やテレビなどで,「シリコン」 
といら語をよく目にする割には, 多くの方は実際に $\mathrm{Si}$ を見たり，いわんや手に取ったりする機会はないのでは ないだろうか。一般には，Si とシリコーンを混同して 豊胸材のイメージが強く, ゾル状の物質を思い描く方が 圧倒的に多いようである（筆者は, 大学院の講義でも, こう思い込んでいる学生が結構いることに驚いたことが ある)。そこでSi ウェー八を壊してみて, 脆性破壊を体 験してもらい, 比較の対象にアルミの度学破壊をという わけである。筆者の研究グループには, 使わなくなった Si ウェーハや実験装置を作った残りのアルミ板がたく さん転がっているので, 費用もかからない。

Si ウェー八を手で割った経験を, 読者の中でどのく らいの方がお持ちだろうか。あるいは, ダイアモンドカ ッタでスクラッチをつけた後で䢃開しようとして失敗 し， ウェーハがバラバラになって途方に菒机たととのあ る方の方が多いかもしれない。Si とアルミ合金は, 一 見すると両方とも同じように金属的に見える。しかし， 同じ $0.5 \mathrm{~mm}$ 程度の厚さの薄片を手にとって曲げてみる と, アルミは簡単に曲がるのに対し，Si は多くの場合， 一瞬にして Fig. 2 の右側のよらにバラバラの小片に割れ てしまう。一方,アルミも一度曲げたところを元に戻し， 同じところを何度も絽り返し曲げていると，次第に端か ら龟裂が入り, 最後はポロリと割れてしまう。いわゆる 疲労破壞による破断である。割れた楽面を見てみると, $\mathrm{Si}$ の断面は光沢があり, 平らな部分が集まってできて いることがわかるが, アルミの方は凹凸が激しい。

この差はもちろん, 共有結合と金属結合の相違に基ら く。Si の䋣開性は, イオン結晶や $\mathrm{GaAs}$ など化合物半導 体のような切れの良さとは異なり, 応力集中が起こらな い状況で割ろらとすると，上記のような制御不能な結果 になる。アルミと Si は周期律表で隣り合う元素である。 1 原子あたりの電子の数がわずか 1 個连うだけで, この ような差が現れる。原子の個性の差が，材料のマクロな

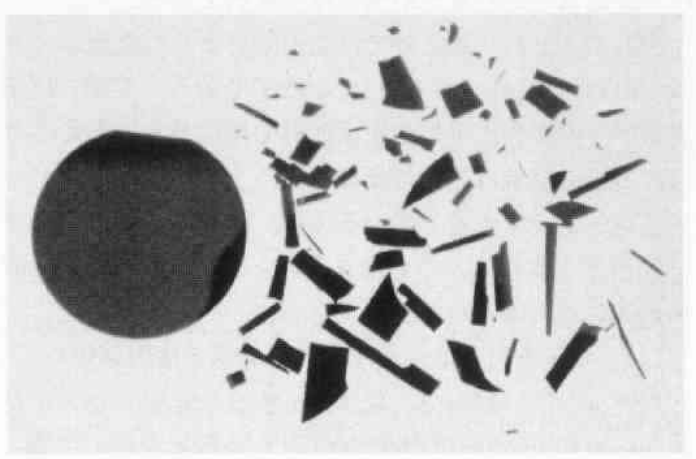

Fig. 2 Photograph of a Si wafer of $60-\mathrm{mm}$ diameter, and crumbled pieces of a wafer.
スケールの特性を規定している好例で，この簡単な実験 を種に，いろいろな説明が展開できる。

\section{3 原子をこわしてみよう一手作りガイスラー管}

では，原子そのものの個性を見てみるにはどうすれば よいだろうか。最も簡単で直接的なのは, 低圧気体の放 電で原子を壊してみることである。

理科実験用のY字ガラス管（9 mm 径， $300 ） の 2$ 本の口に太めの針金を差し込み, 挿入口をエポキシ接着 剤でふさいで真空シールし，ガイスラー管（放電管）を 作る (Fig. 3 上)。次に Fig. 3 下のよ5に, Y 字管の根本 の口に, コム管を介して使い捨て注射器を接続する。最 近の使い搭て注射器 (ポリプロピレン媻, 容量 $50 \mathrm{cc}$ 位, ¥200）はシールが愎れていて，十分に真空ポンプの代 わりを果たす。ガイスラー管の針金電極に $2 \sim 3 \mathrm{kV}$ の高 压を接続しながら, 注射器のピストンを引いて管内を減 圧すると，放電が始まり発光が見られる。減圧のはじめ は系状の放電だが，十分に圧力が下がると，管全体が発 光するようになる。この時, 注射器を接続する前に, 注 射針（注射器とセットになっている）を使って, 空気以 外のガス, 例えば NeやArガスを導入しておくと, ガ スの種類によって色が変わる。印象的なのはやはり赤く 光る Neだ。Ne は放電しやすく, 電極間距離や印加電 圧によっては, 減圧する前から放電が始まる。

この实験では, 高電圧をかけている部分に近いところ を手でつかまねばならないのが奬念される。そのため,

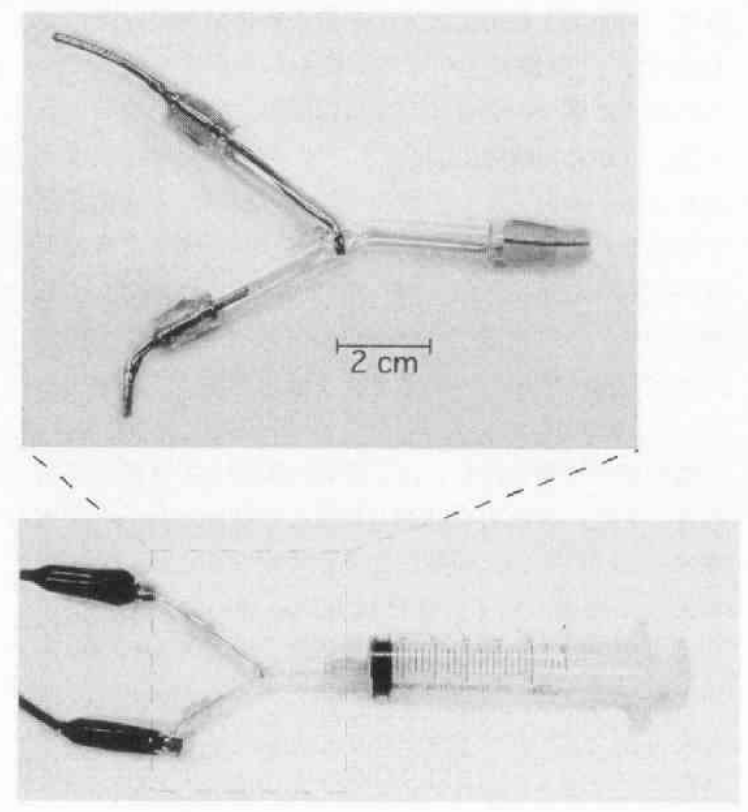

Fig. 3 A handmade discharge tube (upper) and a whole setup of gas discharge experiment (lower). 
電流容量の小さな電源を使うとともに，結線の終端部に $5 \mathrm{M} \Omega$ の抵抗を挿入している。我々はワニロクリップで ガイスラー管の針金電極に接続しているので，クリップ の中に抵抗を仕込んでいる。が，これまでのところ，誤 って高圧に触れた事例は皆無である。注射器を引いて減 圧するのは, 意外と力がいる。そのため, 小中学生の女 子生徒には発光を見るのは, ちょっと難しい。しかし， 真空ポンプではなく, 自力で減圧して発光が始まるのを 見るのは, 印象的である。繰り返して試みるらちに, 陽 極部と陰極部で放電の様子が違うことに気づく, 注意深 い人も現れる。

さてここで減圧下での放電と発光という現象を持って きたのは, 電気の力で, 正確に言うと電子線衝撃で原子 が壊れること, その時, 励起状態の原子あるいはイオン から特有の波長の発光が起こることを, 体験してもらう ためだ。我々の研究所では, 反応の励起にプラズマやレ 一ザ照射, あるいは電子線衝撃がいたるところで活躍し ている(これは, 最初の実験で, 鉛の表面から酸化層を はぎ取り，活性な表面をむき出しにしたことに相当す る)。また，原子や分子の同定に, LIF (Laser Induced Fluorescence）を始めとするスペクトロスコピーを多用して いる。このような反応励起やスペクトロスコピーの最も 簡単な実例が，ここで紹介した実験である。その意味で, 放電からの光を分光して，いくつかの孤立した発光線か ら成り立っていることを示せればもっと，理解が深まる かもしれない。

このデモ実験に基づき，原子の成り立ち，あるいは原 子間の相互作用に電気的な力が本質的な役割を果たして いるということを説明している。そういう状況を本当の 原子でなくとも，モデル原子，つまり鋼球を使って眺め てみようと言うのが次の企画である。

\section{4 「モデル原子」を並べて結晶を作ろう一静電力に よる鋼球の凝集とレーザ回折}

ボールベアリングの玉は高精度の球で, 比較的安価で 大量に入手できるので，いろいろなモデル実験に便利で ある。ここでは, 箱の中に並べて 2 次元の結晶を作り， その構造をレーザ回折で見る実験と, 静電気力で鋼球を 集合させて 2 次元の「クーロン結晶」を作る実験を紹介 する。

2 次元の鋼球結晶を作る目的には, 直径 $0.5 \mathrm{~mm}$ のベ アリング球を使った。後で, この結晶の構造を $\mathrm{He}-\mathrm{Ne}$ レーザの回折で観察する目的には, この程度, 小さな球 を使う必要がある。ただし, 直径が $1 \mathrm{~mm}$ を切ると, 価 格が急速に跳㱛上がる $(0.5 \mathrm{~mm}$ で 1 個 $¥ 2$ 位)。これを, ちょらどこの鋼球が動き回れるだけの深さの, 薄い透明 な箱に入れて, 適当に摇すっていると鋼球の結晶（3 角

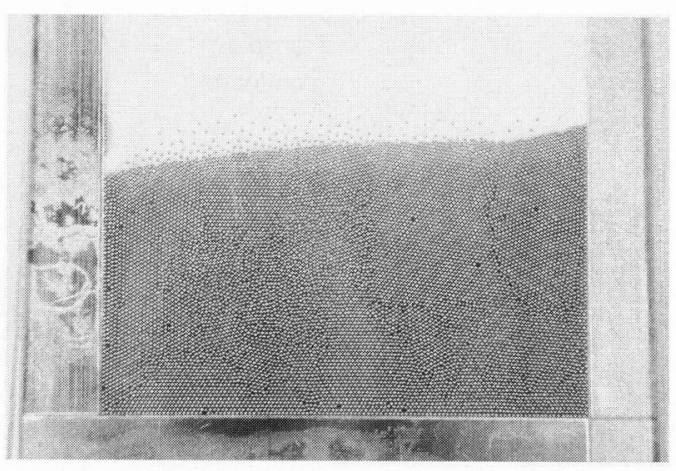

Fig. 4 Two-dimensional polycrystals consisting of steel bearing balls of $0.5-\mathrm{mm}$ diameter.

格子）が成長する（Fig. 4)。箱の内法が深すぎると，鋼 球が重なってうまく 2 次元に並ばない。この箱は, 透明 なアクリル板（厚さ $5 \mathrm{~mm}$, 塩ビ板は剛性と透明度の両 方に欠け, 不適である）を $10 \mathrm{~cm}$ 角程度に切ったものを 2 枚用意し, 鋼球と同じ厚さのスペーサ板（2.2 節で使 った $0.5 \mathrm{~mm}$ 厚のアルミ板）をはさんで両面テープで張 り合わせて作った。もちろん張り合わせるときに適当な. 数の鋼球を入れておく。両面テープは思いの外, 厚さが 均一で, このような $0.1 \mathrm{~mm}$ 精度の「精密加工」に耐え る。この箱を光学実験用のアームに配置して OHP (Over

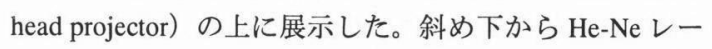
ザを照射し，スクリーンにレーザの回折スポットと同時 に，OHPを使って実像を見せようという意図である。 鋼球が規則正しく並んだ結晶部分よりも, レーザ光が空 格子点や積層欠樎などの欠陥部分を捕らえたときの方 が, 特徴的な回折パターンが得られ, 実像との比較で様々 に楽しめる。

次の Fig. 5 の仕掛けで直径 $1 \mathrm{~mm}$ の鋼球を静電的に集 合させる。これは, 透明電極 2 枚でギャップが $5 \mathrm{~mm}$ の 平行平板のキャパシタを作り, その間に鋼球をはさんだ 構造である。下面は全面が透明電極であるのに対し, 上 面は, 中心付近の数 $\mathrm{cm}$ 径だけが電極にしてある。この 構造を作る材料には, ネサガラスなどを塗布したガラス 板が市販されている（例えば, フルウチ化学で $100 \mathrm{~mm}$ 角 10 枚, 15,000$)$ のが使える。透明導電層は, ワッ クスで覆って酸で溶かすと, 望みの形状にできる。これ を OHP に乗せ, 鋼球の様子をスクリーンに映す。

上部の透明電極の電圧を掛けないときには, 鋼球の位 置はランダムで, 全体を摇すると自由に動き回る, いわ ば気体状態である。ところが，1 2 kV 程度の直流電圧 を掛けると, 上部電極が中心部にしかないので, それに 引かれて鋼球が集まってくる。同時に鋼球も帯電するの 


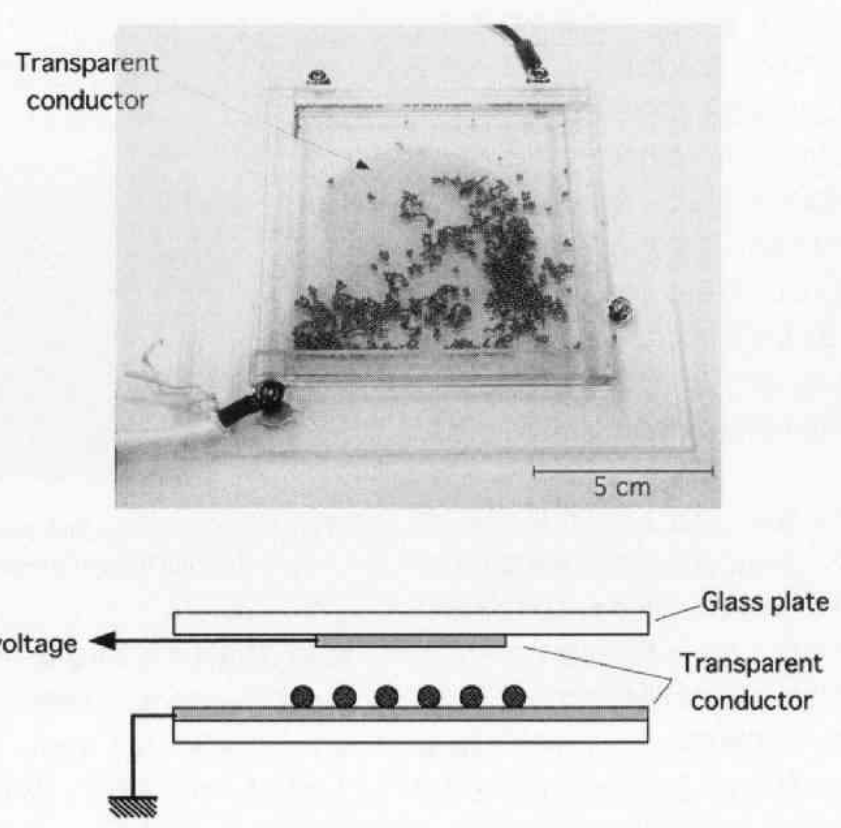

Fig. 5 Formation of Coulomb crystals assembling steel bearing balls by electrostatic forces.

で, 静電反発でお互いには近つけない。結果として, 鋼 球はほぼ等間隔に並び, クーロン結晶（もどき, 完全に 規則的にはならない）になる。この結晶は, 䡫く摇すっ た位では融解しない。この状況は, 実際の原子で起こっ ていることと良く似ている。適当な引力と哌力があれば, 規則正しい構造がひとりでに作られ，方向性の力がない 場合には, 最密充填構造ができる。また, 原子の並び方 を観察するために, 波の回折と干涉が有効であることは, 本紙の読者には説明するまでもない。

正直に言らと,このモデル原子を使う実驗は, 同僚の 研究者には大いに受けたものの, 対照的に, 一般の参加 者にはあまり反響を呼ばなかったようである。やはり， モテル結晶のレーザ回折やクーロン結晶のおもしろさを 感得するには, 実際の原子を相手に苦労した経験が必要 なのかもしれない。Fig. 5 で加える電圧を上げて行くと, 鋼球が静電力で飛び上がる。鋼球が上部電極に触れたと たんに荷電状態が反転し, 逆に下向きに加速され，また 下部電極で反転して，ということを繰り返して，ポップ コーンを炒っているよ5に鋼球が騒がしく飛び跳ねる。 この方が一般受けしていたが，電圧を制御して物体の状 態を変えるということを体験する目的には，それでも良 かったかと思っている。

静電力にこだわるのは, 筆者の携わっている研究に特 有の理由がある。我々はイオントラッブを使って, 主に
Si のクラスターを成長し2), 固体表面に堆積する実験を 行っている。つまり,イオンに対する静電力を物質操作 に使っているわけである。公開用に交流 $(50 \mathrm{~Hz})$ を使 らトラップを作り, 発泡スチロールの小片やアルミナの 粉を浮遊させて見せたが，本稿では省略する。

\section{5 量子の世界にふれてみよう一電流の量子化}

最後を締めるのが, 導電体が極小さな点で接触してい るポイントコンタクトで見られる電流の量子化である。 これはこ承知の通り, ミクロな世界や極低温での超伝導 のような特殊な環境でしか現れないと, 確か大学の講義 で学んだはずのプランク定数 $h$ が, 通常状態での電気 抵抗に手品のように姿を現す, 研究者にとっても夢のよ らな現象である。原子の世界の体験コースに, これを使 わない手はない。

電流の量子化を観測するには, いろいろなやり方があ り，極狭いチャネルを介して電流が流れる状況を作りさ えすればほほとんどどんな場合でも見られることが知ら れている。最も簡単なのが 2 つ導体を近つけけて接触し 始める瞬間か, あるいは, 接触させた導体を引き離して

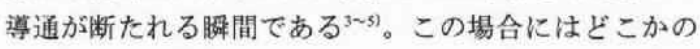
時点で, 原子的なスケールで $2 つ$ 導体がつながってい る状況が出現するはずである。例えば 2 本の導線を軽く 接触させて台の上に置き，それを紙相捲のようにとんと んと叨いて導線を振動させるだけでよい゙。 
このような完全なあなた任せではなく，もう少し，自 分の手でこの現象を制御しながら発現させている実感を 味わってもらうために，筆者らは Fig.6のような道具を 作った。これは, 板バネの弾性変形を利用してマイクロ メータの動きを縮小して $0.1 \mu \mathrm{m}$ 以下の直線運動を作り, 金線を金の箢にわずかに接触させて再び離すのが目的で ある。この弾性変形機構は一応，予定通りに働くが，実 際には, 支持支柱の強度が十分でないため, マイクロメ ータのつまみを指で押すと, この程度の変形が生じてし まう。そこでマイクロメー夕は実験前の位置調整に用い ることにした。実際にポイントコンタクトを作るのに，

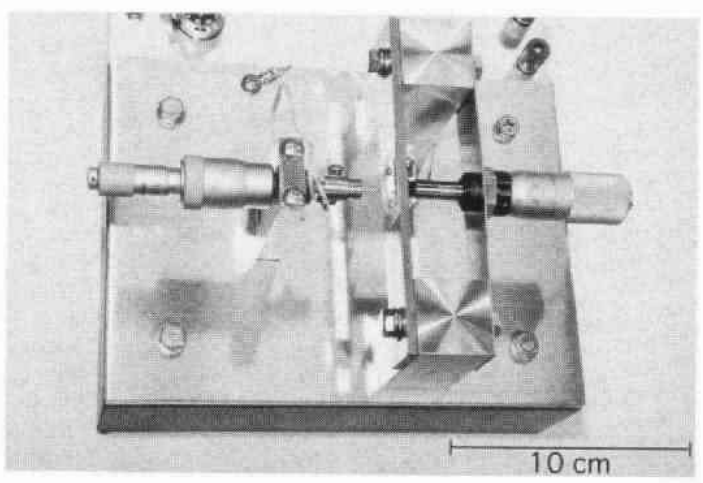

Fig. 6 Measurement setup of quantum point contact.
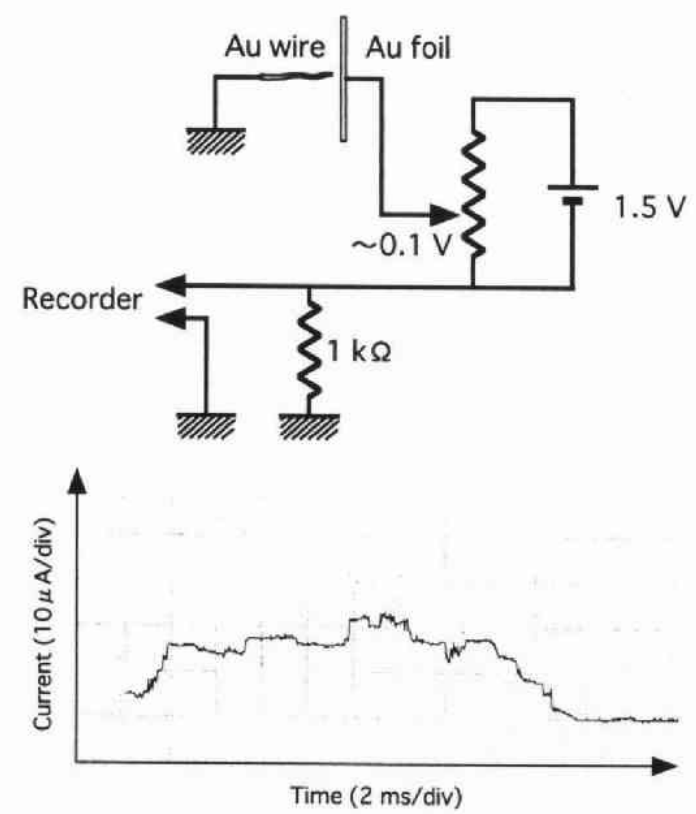

Fig. 7 Measurement circuit of quantum point contact (upper) and an example of record chart (lower).
見学者の方々にマイクロメータの尾部を軽く押し，導通 が見られたら離すという操作をしてもらった。ポイント コンタクトを安定に作るために, いろいろな方法が提案 されている゙。興味のある方には, 㥞々にアイディアを 思い描いて楽しい時を過ごすことをお勧めする。

測定回路は至って簡単で, Fig. 7のように電池の電圧 を抵抗で分割し， $100 \mathrm{mV}$ 程度の電圧を测定端に加える。 回路には $1 \mathrm{k} \Omega$ の抵抗が挿入してあり, その両端の電圧 を液晶ディスプレー付きのレコータ（HIOKI 製 8804, $¥ 190,000)$ で記録することで電流を測定した。このレ コーダにはトリガー機能があり，導通が始まった時点か ら，測定を開始できる。そこで，レコーダが測定を終了 した後に記録を眺めてみて，導通の断続点を探すことが できる。こうすると，図のよ5に階段状に電流傎が変化 する結果が得られる。このレコーダには, 感熱プリンタ がついているので, 希望者には测定結果をプリントして 差し上げた。

さて, 電流の量子化の原因を復習してみよう。電流の 量子化とは，原子のスケールの狭い領域を電流が流れる 時, コンダクタンスが

コンダクタンス $=1 /$ (電気抵抗 $)=\left(2 e^{2} / h\right) \times$ 整数 と, プランク定数 $h$ と電子の電荷 $e$ で決まる定数 $=1$ / $(12.9 \mathrm{k} \Omega)$ の整数倍に，量子化される現象である。この 原因は，原子のスケールのチャネルを電子が流れる時に は, 量子効果により電子のとりらる状態の数が制限され るため,

電流 $=2[$ スピン多重度 $] \times e[$ 電子の電荷 $]$ $\times(e \times$ 電圧 $/ h \times$ 整数 $)$ [電流を運占状態の数] となることに, 基づく。これを直感的にわかりやすくど う説明するか, 研究者にとって量子力学をどれだけ自分 のものにしているかが問われる，腕の見せ所である。少 なくとも我々の研究所に見学に来ようかという方の中で は, 量子力学とか電子のスピンとい5言葉を知っていて 興味を抱いている人は，かなりの割合に上るらしい。知 識のある方は, このような簡単な道具でミクロな現象が 見えることに驚くとともに, 量子力学が実際の研究内容 や現在の技術動向にど5関わっているのかに関心を寄せ られる。説明者の対応が良ければ，いろいろな議論が楽 しめること, 請け合いである。

\section{3. おわりに}

何と言っても，実験屋にとってすべて手作りの道具立 てで，意外な結果がすぐに目で見えるというのは，最も 知的好奇心をそそられる作業である。筆者がこの公開実 騃を準偏していると，同僚に楽しそうですねと冷やかさ れもした。しかりである。本人が楽しんでいなければ, 
人を楽しませることはできない。同様な試みをされてい る研究機関は多々あると思うが，ここで紹介した内容が 少しであ参考になれば幸いだし，いろいろなアイディア や異なった視点をお持ちであれば，笋者にご教示下さる とありがたい。

\section{文献}

1) ガリレオ工房・滰川洋二編著: “物理がおもしろ
W!!" (日本評諭社, 1995) p. 199.

2) 金山敏彦, 宮崎刚英 : 表面科学 18, 134 (1997).

3) J.L. Costa-Kramer, N. Garcia, P. Garcia-Mochales and P. A. Serena: Surf. Sci. 342, L 1144 (1995).

4) J.M. van Ruitenbeek, A. Alvarez, I. Pineyro, C. Grahmann, P. Joyez, M.H. Devoret, D. Esteve and C. Urbina: Rev. Sci. Instrum. 67, 108 (1996).

5) U. Landman, W.D. Luedtke, B.E. Salisbury and R.L. Whetten: Phys. Rev. Lett. 77, 1362 (1996). 